Poznańskie Studia Teologiczne 29(2015), s. 117-138. doi: $10.14746 /$ pst.2015.29.7

Janusz Nawrot ${ }^{1}$

Uniwersytet im. Adama Mickiewicza w Poznaniu

Wydział Teologiczny

\title{
Teologiczna symbolika wybranych postaci historii Izraela w mowie Matatiasza (1 Mch 2,51-61)
}

\section{Wstęp}

Mowę przedśmiertną Matatiasza, skierowaną do synów oraz wszystkich uczestników rozpoczętego dopiero co powstania z literackiego i kompozycyjnego punktu widzenia uznać można niewątpliwie za własny twór pisarski samego autora biblijnego. Łączy ona w sobie postulat wierności prawu i przymierzu, na czym zasadza się ówcześnie pojmowany patriotyzm, polegający na miłości do ziemi ojczystej, równoznacznej z obroną tradycji składających się na tożsamość mieszkającego na niej ludu. Służy temu przywoływanie najważniejszych bohaterów dziejów Izraela i ukazanie obecnej walki jako dalszego ciągu tej historii, którą tamci tworzyli. W ten sposób powstańcy wpisują się w ciąg tych, którzy legli u podstaw dziejów swego kraju. Mowy takie, jak ta, której urywek zostanie poniżej zaprezentowany, znane są w Starym Testamencie i odgrywają rolę ostatnich instrukcji dawanych potomnym, jako swoisty testament patriarchy rodu nadany w formie postulatów do wykonania. Omawiane wystapienie Matatiasza wzorowane jest niewątpliwie na biblijnych relacjach o mowach patriarchów narodu wybranego wygłaszanych przed ich śmiercią: Jakuba (Rdz 47), Mojżesza (Pwt 32) czy Dawida (3 Bas 2) 2. Także Matatiasz zostaje postawiony w rzędzie tych,

\footnotetext{
${ }^{1}$ Janusz Nawrot, ur. 10.05.1960 r. w Międzychodzie, woj. wielkopolskie; święcenia kapłańskie 1985 r. w Poznaniu; tytuł profesora nauk teologicznych otrzymany w 2013 r.; publikacje książkowe: Zagłada Asyrii w teofanicznej symbolice ognia. Analiza tekstu Iz 30, 27-33, Poznań 2000; Przyjaźń i jej motywacja w Etykach Arystotelesa, pismach madrościowych Septuaginty oraz w Nowym Testamencie, Poznań 2004; «Badź mężny i mocny ponieważ Pan jest z tobq». Andreia i jej motywacja w Biblii greckiej, Poznań 2006; "Prześladuja biedaka i nieszczęśliwego». Niegodziwcy wobec sprawiedliwych w psalmach suplikacji, Poznań 2007; «Ustysz, o Panie, moja modlitwe, odpowiedz mi w swej sprawiedliwości! שפה $i$ wolaniem w zagrożeniu życia w psalmach suplikacji, Poznań 2009; Kryzys religijny w Judei za Antiocha IV Epifanesa. Teologia historii w 1 Mch 1,1-2,26, Poznań 2012. Obecnie pracuje na Wydziale Teologicznym UAM w Poznaniu; jannaw@amu.edu.pl

${ }^{2}$ Autor artykułu stosuje greckie nazwy niektórych ksiąg zawartych w Septuagincie, czyli greckim Starym Testamencie. I tak: $1 \mathrm{Sm}$ to 1 Bas, $2 \mathrm{Sm}-2$ Bas, $1 \mathrm{Krl}-3$ Bas, $2 \mathrm{Krl}-4$ Bas, $1 \mathrm{Krn}$
} 
którzy w przekonaniu autora biblijnego odegrali najważniejszą rolę w historii swego narodu. Część jego wywodu mieści się po pierwszej zachęcie do walki w obronie praw ojczystych (2,49-50), a przed drugą zachętą do męstwa (2,62-64). Po krótkich instrukcjach dotyczących rozłożenia odpowiedzialności za losy powstania na poszczególnych synów $(2,65-66)$ następuje trzecia zachęta do walki i wierności Prawu (2,67-68). Podane niżej przykłady wielkich postaci historii Izraela, ukazanych w kolejności chronologicznej, mają wspólną płaszczyznę rozważań, jaką jest przeżywanie wielkich nieraz trudności życiowych, których stali się uczestnikami i które pokonali siłą wiary w sprawiedliwość i wierność Boga. Ma się to stać niepodważalnym punktem odniesienia dla tych, którzy obecnie podejmą walkę za swój naród. Ten sam motyw wspomnienia trudów życia poprzednich pokoleń zawarty został także w mowie Judyty zachęcającej do oporu przeciw najeźdźcom (Jdt 8,26-27) ${ }^{3}$, a także starego Tobiasza pouczającego syna o konieczności bycia wiernym izraelskiej tradycji małżeńskiej $(\mathrm{Tb} 4,12)^{4}$. Budowa każdego z wersetów jest jednolita, oparta na wyliczeniu wpierw próby rodzącej konkretną cnotę, potem zaś nagrody, jaką otrzymują ci, którzy w tej próbie

- 1 Par, 2 Krn - 2 Par oraz grecka nazwa Księgi Jeremiasza jako Ier z numeracją jej odpowiednią, tam, gdzie różni się ona od hebrajskiej. Tego samego dotyczy zmiana wielu psalmów, które w wersji greckiej mają różną numerację od hebrajskiej. We wszystkich rzeczonych miejscach księgi te zostały zaznaczone kursywą jako niepojawiające się w Biblii hebrajskiej. Osobno kursywą zaznaczone zostały księgi apokryficzne, nienależące do zbioru ksiąg biblijnych w kanonie Kościoła katolickiego, lecz zawarte w zbiorze Septuaginty.

${ }^{3} \mathrm{~W}$ przemowie bohaterki pojawiają się również postaci Abrahama, Izaaka i Jakuba z ogólnym i niespecyfikującym odwołaniem do sytuacji, od których zależała dalsza część ich życia. Historia ich losów każe spojrzeć na nie raczej z perspektywy oceny ogólnej, jako na pewną sumę większych i mniejszych prób, jakim zostali poddani, jednak zawsze z podkreśleniem, że próby te przeszli pomyślnie. Ze strony Boga nie są one karą lecz doświadczeniem Jego opiekuńczej miłości poprzez trudności żądające heroicznego nieraz zaufania, by ostatecznie przetrwać czas uciążliwości, por. D. Doré, Le Livre de Judith ou la guerre et la foi, Cahiers Évangile 132, Cerf, Paris 2005, s. 27. Taki sposób przekazu zbliża także ku nowotestamentowej ocenie dziejów patriarchów, por. H. Langkammer, Księga Tobiasza. Księga Judyty. Księga Estery. Ttumaczenie, wstęp i komentarz, Pismo Święte Starego i Nowego Testamentu w przekladzie z języków oryginalnych, RW KUL, Lublin 2001, s. 126-127.

${ }^{4}$ Wierność ta charakteryzuje się przedłużeniem tradycji ożenku wewnątrz klanu, z mocnym zakazem brania obcej żony. Jest to związane najprawdopodobniej z koniecznością pielęgnowania wspólnej wiary, bardzo utrudnionej, jeśli nie wręcz uniemożliwionej w przypadku żony niepochodzącej z Izraela, zatem poganki, mogącej usidlić męża i skłonić go do odstępstwa, co zdarzało się wcale nierzadko w historii narodu (np. $1 \mathrm{Krl}$ 11,3-8), por. także C. Schedl, Księga Tobiasza. Historia Starego Testamentu, t. V: Ku petni czasu, Tuchów 1995, s. 134-152; J.S. Synowiec, Mędrcy Izraela, ich pisma i nauka, wyd. Bratni Zew, Kraków 1990, s. 235-248. Naśladowanie patriarchów jest także gwarancją błogosławieństw na mocy prawa, któremu właśnie oni pozostali wierni, por. M. Wojciechowski, Księga Tobiasza, czyli Tobita, Nowy Komentarz Biblijny - Stary Testament, t. XII, Ed. św. Pawła, Częstochowa 2005, s. 84-85. Tej samej linii mają się teraz trzymać walczący o prawo i ojczyste tradycje powstańcy. 
wytrwali. Taki układ żywo przypomina Chrystusowe błogosławieństwa na górze (Mt 5,3-12) $)^{5}$ Podobny zestaw bohaterów historycznych prezentuje także Syr $44,16-49,16^{6}$ i 4 Mch $18,11-19^{7}$.

\section{Tekst biblijny}

\section{Wstęp $(2,51)$}

Wskazana w w. 51 pamięć o dziełach wybitnych przodków, obok uświadomienia sobie wartości i konieczności przymierza, jest jednym $\mathrm{z}$ fundamentów obecnej walki o jego odnowienie w Izraelu. Powstańcy mają walczyć nie tylko dlatego, że trzeba ponownie odbudować związki przymierza między Bogiem a narodem wybranym, lecz także wpisać się w ciąg tych, którzy wychwalani są przez księgi święte jako przykłady wiary i wierności temuż Bogu. O tym, że w przekonaniu autora biblijnego oba te uzasadnienia nie są od siebie niezależne, lecz ściśle się ze sobą wiążą, świadczy poprzedzający obecny tok myśli w. 50, w którym nastapiło połączenie motywu „przymierza” z „ojcami”, właśnie jako przymierza $\mathrm{z}$ nimi zawartego ${ }^{8}$. W ten sposób rysuje się wzajemna i nierozerwal-

${ }^{5}$ Por. F. Gryglewicz, Księgi Machabejskie. Wstęp - przekład z oryginału - komentarz, w: Pismo Święte Starego Testamentu, red. S. Łach, t. VI, cz. 4, Pallottinum, Poznań 1961, s. 72.

${ }^{6} \mathrm{~W}$ tym bardzo obszernym wyliczeniu najważniejszych postaci dziejów Izraela, a nawet całej ludzkości, ważną rolę odgrywa wstęp w. 1-15, akcentujący zwłaszcza postępowanie ich potomstwa, przedłużające dokonania tamtych szczególnie poprzez wierność prawu i przymierzu (w. 11-13), co adekwatnie odpowiada sytuacji przeżywanej aktualnie przez powstańców machabejskich. Autor księgi - podobnie do wyliczenia postaci w $1 \mathrm{Mch}$ - skupia się tylko na tych, którzy pozostawili po sobie potomstwo godne ich samych, por. M. Gilbert, Les cinq livres de Sages: Les Proverbes de Salomon. Le livre de Job. Qohélet ou l'Ecclésiaste. Le livre de Ben Sira. La Sagesse de Salomon, Lire la Bible, Cerf, Paris 2003, s. 219. Jeśli nawet chodzi tu o potomstwo w dosłownym znaczeniu, nie przeszkadza to w odniesieniu całości cytatu do potomstwa dziedziczącego wiarę. W takim układzie treści można dopatrywać się pewnej istniejącej w późnej starożytności Izraela tradycji teologicznej przywoływania i podkreślania wartości życia przodków jako fundamentu uzasadniającego konieczność pozostania wiernym korzeniom własnego narodu, por. A.A. di Lella, The Wisdom of Ben Sira. A New Translation with notes by P.W. Skehan. Introduction and Commentary, The Anchor Bible 39, New York-London-Toronto-Sydney-Auckland 1987, s. 501-502.

${ }^{7}$ Cytowane przez autora apokryfu teksty biblijne prezentują grosso modo wartość życia danego od Boga, nawiązując wyraźnie do motywu śmierci męczenników prześladowanych za wiarę i dobrowolnie z życia rezygnujących, por. M. Wojciechowski, Apokryfy z Biblii greckiej, Rozprawy i Studia Biblijne 8, Vocatio, Warszawa 2001, s. 198.

${ }^{8}$ Zwrot diathēkē paterōn hèmōn, 'przymierze naszych ojców' zanotowany został już w 2,20 w deklaracji wiary Matatiasza. W tradycji deuteronomistycznej odwołuje się on przede wszystkim do przymierza, jakie Bóg niegdyś zawarł z przodkami narodu wybranego, o którym On zawsze pamięta i któremu pozostaje wierny (Pwt 4,31; 7,12; 8,18; 9,5; Sdz 2,1.20; 3 Bas 8,31; 2 Par 34,32; 2 Mch 8,15; Ml 2,10; Jr 11,10; Ier 38,32; 41,13). Z tej też racji samą diathēkē należy rozumieć nie w sensie konkretnego przymierza, lecz wszystkich, jakie Bóg zawarł ze swoim ludem, począwszy 
na zależność: nie można walczyć o przymierze, jeśli pomija się dokonania poprzednich pokoleń, a z drugiej strony naśladowanie tych, którzy już przeminęli, oznacza trwanie $\mathrm{w}$ przymierzu $\mathrm{z}$ Bogiem jako najważniejszym dokonaniu ich życia. Powstańcy swą gorliwością i zdecydowanym działaniem wchodzą zatem w grono tych, którzy zapobiec mają rozlewaniu się bałwochwalstwa w Ziemi Świętej. Obowiązek oddania życia oznacza niewątpliwie całkowite poświęcenie się sprawie, o którą walczą powstańcy. Dla nich ma ona stać się ważniejsza niż wszelkie dobro ziemskie, do którego podczas życia mogliby się przywiązać, ważniejsza nawet od samego życia. Traci ono bowiem na swej wartości, jeśli nie jest podporządkowane prawu i przymierzu. Wyższość przymierza i prawa nad życiem", a tym samym konieczność jego bezwzględnego zachowania, poświadczona jest wielokrotnie na kartach Starego Testamentu, o czym autor wspomniał już w $1,63^{10}$.

Nakaz pamiętania o czynach ojców autor określa czasownikiem mimnēskomai, 'pamiętam', 'wspominam', łącząc go z ergon, 'dzieło'. Połączenie to w Septuagincie odnosi się wyłącznie do wspomnienia przez człowieka dzieł Boga ${ }^{11}$ i z tego powodu ma na celu uzmysłowienie sobie wszystkiego, czego dokonał On dla dobra swego ludu. Ewidentnym celem takiego wspominania jest ciagłe wychwalanie Boga i uświadamianie swej absolutnej zależności od Niego. Przypominanie to ma charakter kultyczny i liturgiczny, co objawia się zwłaszcza w psalmach ${ }^{12}$. W świadomości autora Pierwszej Księgi Machabejskiej nie ma oczywiście mowy o jakimkolwiek zrównywaniu tego, co uczynili niegdyś przodkowie narodu, z dziełami Wszechmogącego. Tymczasem jeśli w licznych wymienionych konstrukcjach gramatycznych, odniesionych bezpośrednio do Niego, On sam wychwalany jest jako Twórca świetności swego ludu, to obecnie nic nie stoi na przeszkodzie, by wychwalać Go za pośrednictwem ich dokonań. Wszystko bowiem, co osiągnęli, było przecież zawsze zgodne z Jego wolą i Jego poleceniem w ramach zawartego wcześniej z nimi przymierza. Ono właśnie stało się fundamentem i niejako spiritus movens całego ich późniejszego życia, jego przemiany i wzrostu. Ono także całkowicie nakierowało ich ziemską egzystencję właśnie na Tego, z którym zostało przez nich zawarte.

od Abrahama (Rdz 17,2), przez Mojżesza (Wj 24,8; Pwt 28,69), Jozuego (Joz 24,25), skończywszy na Dawidzie (2 Bas 23,5) i Jozjaszu (4 Bas 23,3).

${ }^{9}$ Jednak ze świadomością konieczności walki czynnej o nie, nie zaś biernego poddawania się losowi, jak w dotychczasowym sposobie oporu, prezentowanym w rozdziale 1 omawianej księgi.

${ }^{10}$ Por. m.in. Rdz 17,14; Wj 31,14-15; 35,2; Kpł 26,15-16.25; Pwt 4,1; 8,1; 11,8-9; 30,17-20; Iz 55,3; Am 5,14; Ml 2,5.

${ }^{11}$ Por. Ps 76,12; 142, 5; Hi 36,24; Syr 42,15; Ha 3,2.

${ }^{12}$ Znakomite studium na ten temat napisała K. Mrozek, por. Rdzeń zkr w aspekcie pamięci o Bogu w Księdze Psalmów. Analiza egzegetyczno-teologiczna, Wydział Teologiczny UAM, Poznań 2013, ss. 330 (nieopubl.). 
Odniesienie do przeszłości celem nabycia aktualnej mądrości postępowania poprzez unikanie bałwochwalstwa stosowane było również na kartach ksiąg świętych. Oto lud ma wspominać przede wszystkim dzień wyjścia niewoli egipskiej, co ukazuje cytat Pwt 16,3. Dokonywać się to ma poprzez spożywanie w ciagu siedmiu dni chleba przaśnego, symbolu upokarzającego zniewolenia łącznie z ofiarą baranka paschalnego. Coroczne wspomnienie staje się tym samym źródłem mądrości życia i ma kierować ku Bogu - Wyzwolicielowi wpierw spod panowania władcy kraju pogańskiego oddanego swym bałwochwalczym rytuałom $^{13}$. Nie trzeba przekonywać, że tekst ów w sytuacji, w jakiej wówczas znajdowali się Żydzi, szczególnie mocno uzasadniał konieczność wiernego trwania przy Bogu, który także teraz mógł dokonać tak samo wielkich rzeczy, jak w dawnej historii swego ludu. Kolejnym ważnym odpowiednikiem biblijnym może być także tekst Pwt 32,7 relacjonujący nakaz wspominania dni zasiedlania Ziemi Obiecanej. Wspomnienie tamtego czasu fundowane jest na wielkości Bożego działania, na mocy którego lud zajął ziemię narodów liczniejszych i potężniejszych od niego. Nie byłby w stanie uczynić tego samodzielnie. Istotą wspomnienia ma być właśnie świadomość, że tak wielkie dzieła mogły dokonać się wyłącznie z Bożą pomocą. Pamięć ta ma przeciwstawić się wzmagającemu lekceważeniu wierności Bogu przez Jego lud - a właściwie potomków tych, którzy zasiedlili Ziemię Obiecana - zbyt szybko zapominających o wyświadczonej łasce (w. 5-6) ${ }^{14}$. Także w tym wypadku powiązanie z obecną sytuacją w kraju Izraela jest całkowicie oczywiste: kolejne pokolenie potomków narodu wyprowadzonego z niewoli i zasiedlającego $\mathrm{z}$ łaski Bożej swą ziemię okazuje się całkowicie niewierne, głupie i bezrozumne.

Chociaż nigdzie w Septuagincie - poza obecnie analizowanym wersetem nie można znaleźć połączenia ergon z patêr, 'ojciec' jest możliwe, że o tych właśnie czynach ojców mają przede wszystkim pamiętać powstańcy, ponieważ oba motywy ${ }^{15}$ bardzo dobrze pasują do całości teologii autora natchnionego: pamięć

\footnotetext{
${ }^{13}$ Jeśli autor 1 Mch nawiązuje do tego właśnie tekstu, możliwe także, że chce zaakcentować konieczność takiego wspominania we wszystkich siedliskach żydowskich, nie tylko w Jerozolimie lub w samych kręgach powstańczych. Prawo o chlebie niekwaszonym obowiązywać miało przecież wszędzie, gdzie znajdowali się ówcześni Izraelici, por. E.H. Merrill, Deuteronomy. An Exegetical and Theological Exposition of Holy Scripture, New International Version - New American Commentary 4, Broadman \& Holman Nashville 1994, s. 252.

${ }^{14}$ W. 5 jest klasycznym oskarżeniem ze strony sędziego, za pośrednictwem swego przedstawiciela, którym w passusie biblijnym jest Mojżesz. Motyw ów znany jest także w literaturze pozabiblijnej. W tekście Pierwszej Księgi Machabejskiej w rolę tę może wcielić się autor natchniony. Stosując w w. 6 pytanie apostroficzne, autor Księgi Powtórzonego Prawa chce wzmocnić efekt szoku w słuchaczach uświadamiających sobie absolutną nieprzystawalność własnego postępowania w odpowiedzi na tak wielkie dobrodziejstwa Boże. W. 6 wysuwa na pierwszy plan głupotę takiego procederu, por. D.L. Christensen, Deuteronomy 21:10-34:12, Word Biblical Commentary 6B, Word Books Publ., Dallas 2002, s. 795-796.

${ }^{15}$ W Ps 105,43-44 motyw uwolnienia z niewoli łączy się z permanentnym sprzeciwem i od-
} 
o wyjściu z niewoli ma ustrzec przed ponownym w nią popadnięciem, zdobywanie zaś Ziemi Obiecanej wzmacnia świadomość, że pobyt w niej ściśle uzależniony jest od wierności prawu Bożemu ${ }^{16}$. Oba wydarzenia ukazują także całkowita wierność członków narodu Bożym nakazom, stanowiąc wyzwanie dla współczesnych powstańcom kolaborantów. Drugim, silnym motywem podjęcia walki za swój naród jest obietnica chwały i renomy. W przeciwieństwie do spojrzenia w chwalebną przeszłość Izraela, obecnie kieruje się ono ku przyszłości i dotyczy już tylko samych powstańców. Wspomnienie u potomnych należy do najszczytniejszych wartości, o które należy zabiegać ${ }^{17}$. Poniższe wyliczenie wspaniałych postaci historii Izraela jest tego najlepszym przykładem. W ten sposób powstańcy mogą wpisać się w ciąg wielkich synów narodu wybranego. Doksa megalē spośród ludzi przyznana została w Septuagincie jedynie królowi mesjańskiemu, wspartemu Bożą pomocą, co ukazuje Ps 20,6, akcentując konieczną i decydującą rolę Bożego działania ${ }^{18}$. Tej samej pomocy w zyskaniu chwały mogą spodziewać się walczący za Bożą sprawę Machabeusze. Natomiast onoma aiōnion, jeśli odnosi do tego, co sam Bóg przygotowuje swemu imieniu poprzez działanie i odbierane uwielbienie ${ }^{19}$, odważnie wskazuje, że przyszła chwała powstańców nie zaniknie tak samo, jak wieczne imię Boga Izraela, za które podejmują walkę. Zgodnie natomiast z treścią $P S 45,18$ oraz 71,17.19 takie imię zaskarbi sobie również król mesjański na fundamencie swych wzniosłych czynów. Warto jednak dodać, że tak wspaniałe uzasadnienie walki nie wychodzi poza chwałę doczesną i u potomnych. Autor, zdaje się, celowo pomija możliwość ewentualnej nagrody pośmiertnej, a wątek ten wyraźnie pojawi się w tekście Drugiej Księgi Machabejskiej $^{20}$.

rzuceniem ze strony ojców posłuszeństwa Bogu, co spotkało się z upokorzeniem powodowanym własną nieprawością. Niemniej jednak autor psalmu dorzuca motyw litości ze strony Boga na fundamencie przymierza i wysłuchania modłów słanych przez ponownie zniewolony lud, por. J. Goldingay, Psalms 3: Psalms 60-150, BCOT: Wisdom and Psalms, T. Longman III (wyd.), Baker Academic, Grand Rapids 2008, s. 237-238.

${ }^{16}$ Por. Lb 35,33; Pwt 6,10-12; 8,7-14; 24,4; 29,24-27; 3 Bas 6,6-9; Jr 3,1-2.9; Ba 2,35.

${ }_{17}$ Por. m.in. Ps 44,18; Prz 10,7; Jdt 8,32; Syr 31,11; 35,6; 39,1-11; 44,7-8.10-15; 45,1; Mdr 4,$1 ; 8,13$.

${ }^{18}$ Motyw blasku i dostojeństwa połączony został z długim życiem, co jeszcze bardziej uwydatnia możliwość czynienia dobra i ukazywania osobistej wielkości. Stanie się to później jednym z czynników fundujących wspomnienie u potomnych. Błaganie o życie może oznaczać wyzwolenie od nieprzyjaciół, por. J. Goldingay, Psalms 1: Psalms 1-41, BCOT: Wisdom and Psalms, T. Longman III (wyd.), Baker Academic, Grand Rapids 2006, s. 314-315. W takim wypadku wspólnota z położeniem powstańców machabejskich jest jeszcze większa. Zachowanie ich życia oznacza spełnienie błagań o zwycięstwo nad poganami.

${ }^{19}$ Por. Wj 3,15; Iz 63,12; por. 2 Bas 7,26; 3 Bas 9,3; 4 Bas 21,7; 1 Par 23,13; 2 Par 2,3; 6,2; 7,16; 33,4.7; Tb 3,11; 8,5; Ps 85,12; 112,2; 134,13; 144,1-2.21.

${ }^{20}$ Józef Flawiusz onoma aiōnion rozumie już jako athanasia, 'nieśmiertelność' przypisując Matatiaszowi - jako faryzeuszowi z pochodzenia - wiarę w życie po śmierci (Ant. XII, 6.3.282). 


\section{Abraham (2,52)}

Nie powinno dziwić rozpoczęcie wyliczenia sławnych mężów historii narodu od jego protoplasty, jakkolwiek nie bez trudności można wskazać, o którym konkretnie epizodzie życia patriarchy myśli Matatiasz. Natychmiast można przywołać gotowość złożenia przez Abrahama ofiary z syna swego, Izaaka (Rdz 22,1$-19)^{21}$. Nie ma bowiem bardziej przekonującego epizodu w karierze Abrahama, który mocniej świadczyłby jego wierze. Epizod ów stanowi niewątpliwie szczytową próbę, jakiej Bóg poddał swego wiernego dotąd sługę. Ta interpretacja napotyka jednak pewne trudności, ponieważ w tekście omawianego wersetu Pierwszej Księgi Machabejskiej pojawia się stwierdzenie, że zostało mu to policzone za sprawiedliwość. Natomiast w Księdze Rodzaju ów zwrot dotyczy wiary Abrahama $\mathrm{w}$ obietnicę potomstwa mimo starczego już wieku $(15,4-6 ; 21,5)$, nie zaś ofiary z syna ${ }^{22}$. Na rzecz ofiarowania Izaaka przemawia natomiast Syr 44,20 zawierający ten sam, co Pierwsza Księga Machabejska, zwrot en peirasmō eurethē pistos, dosł. 'w doświadczeniu znaleziony został wiernym', pojawiający się już po zapisie o obrzezaniu, co w Rdz znajduje się w rozdziale 17. Dla autora Księgi Syracha ewidentne jest, że jedyną taką próbą było złożenie Izaaka przez Abrahama w ofierze ${ }^{23}$. Nasz autor należy więc do zwolenników nurtu teologicznego łączącego sprawiedliwość patriarchy narodu wybranego z wydarzeniem na górze Moria, pojmowanym jako sprostanie poprzez konkretny uczynek wymogom wiary wyrażającej się mocą osobistego zaufania ${ }^{24}$. Można zatem powiedzieć, że ofiarowanie Izaaka pojawia się w ścisłym kontekście obietnicy potomstwa, jako ostateczna próba zawierzenia patriarchy prawdzie słów Bożych, stąd obie interpretacje są tu dopuszczalne ${ }^{25}$. Tak czy inaczej powstańcy stają się obecnie

${ }^{21}$ Por. F. Gryglewicz, Księgi Machabejskie.

${ }^{22}$ Po tej samej linii idzie także egzegeza dokonana przez apostoła Pawła w Rz 4,1-22, zaznaczając szczególnie, że jego wiara poczytana została mu jako sprawiedliwość jeszcze przed obrzezaniem (w. 10-11). Bóg może spowodować, że stary człowiek, niemogący już posiadać dzieci z racji wieku, stanie się ojcem mnóstwa narodów (w. 17-22), przy czym Paweł explicite nie wymienia w tym kontekście ofiary z Izaaka. Tymczasem wydarzenie to może zostać swobodnie włączone w zakres wiary patriarchy, ukazanej w w. 19-20, że Bóg w każdej sytuacji mocen jest wypełnić daną przez siebie obietnicę. Możliwe, że Paweł implicite włączył także ofiarę na górze Moria w całość wiary patriarchy Izraela, por. R.H. Mounce, Romans. An Exegetical and Theological Exposition of Holy Scripture, New International Version - New American Commentary 27, Broadman \& Holman Nashville 1995, s. 126-130.

${ }^{23}$ Por. A.A. di Lella, The Wisdom of Ben Sira, s. 505.

${ }^{24}$ Podobny tok myśli zawiera w Nowym Testamencie także tekst Jk 2,21-23 akcentujący nie tyle samą wiarę patriarchy, ile wynikające z niej uczynki, harmonizujące z nią całkowicie. To dzięki sile wiary Abraham postanowił być Bogu posłuszny nawet podczas próby całkowicie wykluczającej dotychczasowe zobowiązania Boga, por. K.A. Richardson, James. An Exegetical and Theological Exposition of Holy Scripture, New International Version - New American Commentary 36, Broadman \& Holman Nashville 1997, s. 137-141.

${ }^{25}$ Potwierdza to także brzmienie Hbr 11,17-19. Akcent w argumentacji autora pada na kon- 
godni tej samej Bożej pochwały, jaką swego czasu otrzymał wielki założyciel narodu.

\section{Józef $(2,53)$}

W kolejnym wersecie Pierwszej Księgi Machabejskiej podany zostaje drugi przykład wierności Bogu z okresu patriarchów, tym razem z życia Józefa, sprzedanego przez braci do Egiptu (Rdz 37,25-28). Już to wydarzenie należy traktować w kategorii próby, jakiej Bóg poddał swego wiernego. Na takie rozumienie tego incydentu wskazuje mowa samego Józefa wygłoszona w czasie, gdy wszelkie próby przeszedł pomyślnie i został przez Boga sowicie wynagrodzony. Otóż w przemówieniu do braci, już po śmierci Jakuba, zdefiniował własną ocenę wszystkiego, co mu się przytrafiło, jako specyficzne działanie Boże, którego elementem były nawet knowania braci przeciw Józefowi $(\operatorname{Rdz} 50,20)^{26}$. Szczególnym jednak incydentem zasługującym na miano próby był epizod z żoną Potifara, dowódcy straży królewskiej, pożądającej Józefa, będącego wówczas niewolnikiem swego pana, i pragnącej zemsty za odmowę współżycia (Rdz 39,7-20). Godny podkreślenia w opowiadaniu Księgi Rodzaju jest w. 9 ukazujący motywację wiary w Boga jako powód odrzucenia jej zakusów ${ }^{27}$. Passus 4 Mch 2,1-6 akcentuje z kolei wagę rozumu panującego nad namiętnościami, czego Józef jest właśnie najlepszym przykładem. Owo panowanie wyraża się umiejętnością powściagania skłonności wynikających z ludzkiego popędu oraz unikania okazji do jego uwidocznienia się $e^{28}$. Po okresie niesprawiedliwego uwięzienia Józef zo-

frontację próby z obietnicą potomstwa, z której Bóg nigdy się nie wycofuje. Stąd jedyną drogą zaufania mogło być przeświadczenie, że Bóg wskrzesi Izaaka z powrotem do życia, by swą obietnicę wypełnić, por. D. Guthrie, Hebrews, The Tyndale New Testament Commentary, InterVarsity Press, Grand Rapids 1983, s. 235-237.

${ }^{26}$ Tajemnicą pozostanie sposób i moment odczytania dziejących się wydarzeń przez Józefa jako dobra ze strony Boga: czy mógł się tego spodziewać od początku i wówczas zachować swą ufność, a tym samym wierność Bogu mimo niesprzyjających okoliczności, czy poznał to dopiero post factum, wiele lat później. Wówczas jego wierność Bogu przez całe życie wynikałaby z wartości wiary i moralności, jakie wyniósł z domu rodzinnego, por. K.A. Mathews, Genesis 11:27-50:26. An Exegetical and Theological Exposition of Holy Scripture, New International Version - New American Commentary 1B, Broadman \& Holman Nashville 2005, s. 927-928. Późniejsza teologia widziała w splocie tych wydarzeń wyraźną rękę samego Boga prowadzącego swego wiernego sługę (Ps 104,19).

${ }^{27}$ Werset ów portretuje Józefa jako męża nie tylko sprawiedliwego, lecz bogobojnego, działającego zgodnie z późniejszym prawem Izraela (Kpł 20,10; Pwt 22,22), mimo że żył w epoce, gdy tegoż prawa jeszcze nie było. Ukazany został zatem jako postać o mocnym kręgosłupie moralnym, odporna na uderzające ją zło, a tym samym wzorcowa dla późniejszych pokoleń Izraelitów, którzy posiadając prawo, permanentnie je przekraczali, jak choćby Dawid popełniający gwałt na Batszebie, żonie Uriasza, co pod wpływem nagany proroka Natana wyznaje osobiście (2 Sm 12, 13; Ps 51,6), por. K.A. Mathews, Genesis, s. 734.

${ }^{28}$ Por. M. Wojciechowski, Apokryfy z Biblii greckiej, s. 132-133. 
stał zatem nagrodzony przez faraona wysokimi zaszczytami i urzędem wezyra królewskiego (Rdz 39,7-41,46).

Powyższa krótka analiza pozwala uzasadnić wybór Józefa jako jednego z tych, których obecni powstańcy powinni ze wszech miar naśladować. Z jednej bowiem strony jest to mąż głębokiego zaufania, co pozwoliło mu przetrwać w wierności Najwyższemu wszelkie trudne momenty życiowe. $Z$ drugiej zaś potrafił nie składać broni i o swą wierność walczyć uczciwością mając nadzieję na ostateczną odmianę swego losu przez Boga. Podobną postawą powinni zatem charakteryzować się także powstańcy, walcząc o Boże prawo w życiu osobistym i wspólnotowym i pokładając nadzieję w Jego możliwą interwencję dla ich dobra. Zwrot efylaksen entolèn wskazuje zaś na serce szczere i wierne Bogu, co prowadzi do wzrostu mądrości, unikania zła i zachowania życia ${ }^{29}$. Wszystkie te wartości mogą stać się udziałem walczących obecnie o wolność swego narodu.

\section{Pinchas $(2,54)$}

Pierwsza wzmianka o przodku rodu kapłańskiego pojawiała się już w zapisie samego autora oceniającego postawę Matatiasza w 2,26. Przywołana wówczas konkretna postać historyczna Fineesa, czyli Pinchasa, ukazuje sposób egzegetowania przez hagiografa opisywanych przez siebie wydarzeń: wszystko należy odczytywać w teologicznym kontekście historii Izraela jako jej ciąg dalszy, zawsze w ścisłej relacji do Boga, który - chociaż milczy na podobieństwo niemego obserwatora - jest ciągle obecny blisko swego ludu i ma realny wpływ na jego losy. Autor wyraźnie ustanawia więź między oboma kapłanami na fundamencie jednego, konkretnego czynu, wynikającego z gorliwości o Boże prawo w sytuacji krytycznej dla całej społeczności. Pierwowzór postępowania Matatiasza zawiera opis czynu kapłana Pinchasa w kontekście bałwochwalstwa wielkiej liczby Izraelitów, których do haniebnego czynu skłoniły Moabitki w Szittim (Lb 25,1-9). Spowodowało to wybuch gniewu Bożego (w. 3) i nakaz kary śmierci dla wszystkich winowajców (w. 4-5.9). Na tym tle wyróżnia się postępowanie pewnego Izraelity, który przyprowadził do obozu Madianitkę, prawdopodobnie w celu kontynuacji bałwochwalstwa już pośród społeczności, na oczach Mojżesza i wspólnoty (w. 6). Na widok tego właśnie Pinchas w gorliwości o prawo Boże zadał obojgu śmiertelny cios, odwracając w ten sposób plagę od Izraelitów (w. 7-8). Spotkało się to z pochwałą Boga, który wstrzymał wymierzanie kary ludowi (w. 11), sam zaś Pinchas zasłużył na wieczyste przymierze pokoju z Bogiem, skutkiem czego odziedziczy kapłaństwo na wieki i dokona przebłagania za Izraelitów (w. 12-13) ${ }^{30}$. Właśnie do epizodu w Baal-Peor nawiązuje również

${ }^{29}$ Por. 3 Bas 8,61; Prz 4,5; 15,5; 19,16; Koh 8,5.

${ }^{30}$ Jeszcze wiele wieków później gorliwość i czyn Pinchasa wspominane były w tradycji biblijnej (1 Par 9,20; Ps 105,29-31; Syr 45,23-25). Lb 25,14 notuje z kolei imię winowajcy, którym był niejaki Zimri, syn Salu, księcia jednego z rodów z pokolenia Symeona. 
obecnie główny bohater. Warto jedynie podkreślić, że mianem dzēlōsai dzēlon autor określa czyn kapłana Pinchasa, który w obronie prawa przebił włócznią Izraelitę i oddającą się współżyciu z nim Madianitkę. Czyn ów został określony w mowie Boga do Mojżesza właśnie jako dzēlōsai mou ton Delon ('zapłonął moją zazdrością'), co dotyczy zazdrości o chwałę Bożą pośród Izraelitów, naruszoną postępowaniem bałwochwalców. Pozwoliło to wstrzymać szerzącą się plagę śmierci wśród ludu ${ }^{31}$. Nagrodą za tak wyrażoną gorliwość było zawarcie przymierza wieczystego kapłaństwa (diathēkēn hierateias aiōnia, w. 13), do czego nawiązuje zapis $1 \mathrm{Mch} 2,54$, nazywając jedynie kapłaństwo mianem hierōsynēs zamiast hierateias. Termin ów wskazuje, że autor mógł czerpać tu z zapisu Syr 45,23-24 relacjonującego owo wydarzenie w tej samej optyce teologicznej nagrody za „szlachetną odwagę swej duszy”. Istotą wspomnienia tego czynu Pinchasa jest jego zdecydowanie w obronie czystości wiary i prawa Bożego. W świetle Bożych przykazań absolutnie niemożliwe jest wchodzenie w jakiekolwiek kontakty $\mathrm{z}$ poganami ${ }^{32}$. Ów epizod $\mathrm{z}$ historii Izraela stanowi najbardziej bodaj wyraziste wyzwanie rzucone wszystkim zwolennikom hellenizacji kraju. Zostają oni przyrównani do tego swego przodka, który bezczelnie wprowadził pogańską kobietę pod swój dach. Zasługują więc na tę samą karę śmierci, co tamten. Wspomnienie wiecznego kapłaństwa ma w kontekście walki Machabeuszów znaczenie trwałości kapłaństwa lewickiego mimo obecnych, niesprzyjających warunków politycznych w kraju. Urząd kapłański bowiem nie ginie nawet wówczas, gdy nie ma możliwości sprawowania go. Zagwarantowana przez Boga jego wieczność wymusza wręcz walkę o prawo do jego wykonywania na chwałę Boga Izraela. Ponadto stwierdzenie „nasz ojciec” brzmi dla kapłańskiego rodu Matatiasza jak zobowiązanie: jako potomkowie Pinchasa Machabeusze powinni walczyć $\mathrm{z}$ równą gorliwością o prawo Boże i przymierze. Zwrot patēr hēmōn ukazuje odczuwane jako szczególnie bliskie relacje między patriarchą a jego potomkami i naznaczone kontynuacją lub wręcz nakazem powielenia jego zachowania ${ }^{33}$.

\section{Jozue $(2,55)$}

Nie sposób odpowiedzieć twierdząco na pytanie, dlaczego w wyliczeniu bohatera mowy pominięty został wielki Mojżesz, który przecież permanentnie przeżywał próby wierności Bogu, widząc prowadzony przez siebie lud trwający w uporze, niewierności i głupocie. Był to lud ciagle szukający okazji, by sprzeniewierzyć się Bogu i Jego prawu. W wyniku kolejnej kłótni bliski był pragnie-

${ }^{31}$ Szerszy opis, por. B.A. Levine, Numbers 21-36. A New Translation with Introduction and Commentary, The Anchor Bible 4A, Doubleday, New York-London-Toronto-Sydney-Auckland 2000, s. 282-297.

${ }^{32}$ Por. A.A. di Lella, The Wisdom of Ben Sira, s. 513.

${ }^{33}$ Por. 1 Par 29,10; Ier 42,6.10; J 8,39; 4 Mch 16,19-20. 
nia śmierci, by uwolnić się od ciężkiego brzemienia, jakim Bóg go obarczył (Lb 11,15). Być może chodzi jednak o jednorazowy upadek w wierze i zaufaniu do Boga w następnym sporze u wód Meriba, za który Mojżesz ukarany został niewprowadzeniem ludu do Ziemi Obiecanej (Lb 20,10-12). Wskutek tego nie może być zaliczany do tych, którzy wytrwali w sposób doskonały na straży wiary i wierności.

Kolejna zaś część przedśmiertnego orędzia Matatiasza sprawia pewien kłopot, ponieważ nigdzie w Septuagincie Jozue nie był nazwany sędzią. Także w swej wersji hebrajskiej Księga Jozuego nie przypisuje następcy Mojżesza funkcji sędziowskich, opatrzonych rdzeniem $\check{s} p t$, klasycznym dla tego typu działania. Natomiast brzmienie zdania wyraźnie sugeruje, że autor rozumie sędziowską rolę Jozuego na podobieństwo głównych bohaterów Księgi Sędziów, osób eminentnych, obdarzonych charyzmatem walki z wojskami narodów pogańskich, zasiedlających ziemię przeznaczoną dla Izraelitów. Kluczem rozwiązania problemu wydaje się sens terminu logos, pojmowanego jako nakaz: czy chodzi o pojedyncze zadanie, czy całokształt misji do wypełnienia? Dotychczasowy kontekst innych postaci historii narodu wskazuje jednoznacznie, że chodzi o jakąś pojedynczą próbę ukazującą wierność bohatera Bożemu poleceniu. Jednak Księga Jozuego takowej specjalnej próby nie notuje, stąd logos należy chyba rozumieć jako całokształt zadań, jakie Jozue miał do wypełnienia względem ludu. Otóż w myśl passusu Pwt 1,38 otrzymał on od Mojżesza polecenie zajęcia Ziemi Obiecanej ${ }^{34}$, potwierdzone później przez samego Boga (Joz 1,2-9). Można więc ową misję Jozuego pojmować jako jedno wielkie zadanie otrzymane od Boga. Charakterystyczny w niej jest nakaz zajmowania ziemi na rozkaz Boży, oczywiście poprzez walkę z pogańskimi tubylcami w celu usunięcia ich z ziemi, jaką Bóg obiecał swemu ludowi. Werset 5 zapewnia o walkach całkowicie zwycięskich dzięki wspomożeniu samego Boga. Oba te elementy: zajęcie ziemi i Boża pomoc stanowią także fundament rozgrywających się podczas powstania machabejskiego wydarzeń. Są one niejako powtórzeniem tamtych, w których Bóg tak żywo uczestniczył. Powstańcy mogą zatem całkowicie liczyć na Jego wsparcie również obecnie. Werset 6 wspomina o nakazie rozdzielenia ziemi między poszczególne pokolenia po jej zdobyciu, co zdecydowanie można przyrównać do funkcji sędziowskiej. Ponadto w Joz 24,25 widnieje zapis, że Jozue, odnawiając przymierze Mojżeszowe z Izraelem w Sychem, nadał ludowi nomon kai krisin, 'prawo i statuty', w Księdze Sędziów zaś umieszczony został na początku jako pierwszy wódz ludu, za którym przyszli następnie sędziowie ( $\operatorname{Sdz} 1,1-2,10)^{35}$.

${ }^{34}$ Już w Lb 27,18-23 widnieje zapis o ustanowieniu Jozuego wodzem przez Mojżesza z polecenia Bożego. Jest to typowa inwestytura następcy po śmierci poprzednika.

${ }^{35}$ Por. R. Doran, The first book of Maccabees, The new interpreter's Bible, red. L.E. Keck, D.L. Petersen, t. 4, Abingdon, Nashville 1996, s. 50. 
Autor Pierwszej Księgi Machabejskiej korzystał tu zapewne z nieznanej bliżej późnej tradycji żydowskiej widzącej w Jozuem właśnie sędziego rozumianego jako wódz ludu odmiennie od tradycji ukazującej Jozuego jako proroka (Syr $46,1)^{36}$. Jeśli jednak logos rozumieć w ścisłym sensie, jako konkretne polecenie, chodzi najprawdopodobniej o misję eksploracji Ziemi Obiecanej, czego Jozue podjął się wraz z Kalebem (Lb 13,6.16; Joz 14,6). Jako jedyny, obok tamtego, złożył prawdziwe świadectwo o wspaniałości ziemi, zachęcając do jej zdobycia (Lb 14,6-9.38). Tytuł sędziego należy więc traktować jako nagrodę za wierność w chwili próby, jakiej nie podołali pozostali członkowie wyprawy.

\section{Kaleb $(2,56)$}

Umieszczenie Kaleba w mowie Matatiasza wzmacnia tezę, że także słowa dotyczące Jozuego należy raczej rozumieć jako misję w Ziemi Obiecanej, którą jedynie ci dwaj wykonali pomyślnie, optując za jej zajęciem według woli Bożej (Lb 14,9; Syr 46,7-8). Najważniejszym elementem świadectwa Kaleba nie był jednak opis wartości samej ziemi. Tak samo bowiem przedstawiali ją ci, którzy ostatecznie opowiedzieli się przeciw wejściu do niej (Lb 13,27). Natomiast Kaleb podjął próbę powstrzymania rodzącego się buntu opartą na przekonaniu, że zajęcie ziemi jest możliwe, jeżeli lud pozostanie wierny Bożym nakazom (Lb $13,30 ; 14,6-9)^{37}$. Z jego więc postawy mogą obecnie powstańcy machabejscy czerpać wzorzec i siłę do podjęcia własnej walki o sprawę, która po ludzku wydaje się niemożliwa do zrealizowania. Muszą jednak ufać z taką samą moca, jaką wykazał się ich wielki poprzednik, zachęcając do niej także ewentualnych opornych i słabych w wierze. Co więcej, mogą w pewien sposób zmazać winę poprzednich pokoleń, którym tej wiary zabrakło i które same wykluczyły siebie z obiecanego dziedzictwa. Powstańcy nie mogą więc dopuścić do powtórzenia się tamtej sytuacji. Ponadto towarzysz Jozuego gotów był ponieść raczej śmierć, niż odstąpić od wypełnienia woli Bożej (Lb 14,10). Taka postawa musiała zostać nagrodzona decyzją Bożą o wejściu Kaleba i jego rodu do Ziemi Obiecanej ${ }^{38}$, a następnie o otrzymaniu działu pośród innych pokoleń izraelskich ${ }^{39}$. Podobnie powstańcy, podejmując wysiłek walki o utracone dziedzictwo ojców, zyskują

\footnotetext{
${ }^{36}$ Prawdopodobnie na podstawie cytatu Lb 27,18 nazywającego go człowiekiem, „w którym prawdziwie mieszka Duch", co było tak charakterystyczne dla proroków, por. szczegółową egzegezę A.A. di Lelli, The Wisdom of Ben Sira, s. 518-519.

${ }^{37}$ Najważniejszym elementem wołania jest tu odrzucenie strachu przed czekającą walką, bazujące na Bożej życzliwości - skoro Pan doprowadził swój lud do tego miejsca, nie opuści go w żadnym wypadku także później. Strach przed mieszkańcami kraju jest równoznaczny z rebelią wobec Boga, por. T.R. Ashley, The Book of Numbers, The New International Commentary on the Old Testament, Eerdmans Publ. Comp., Grand Rapids 1993, s. 248-250.

${ }^{38}$ Por. Lb 14,24.30.38; 26,65; 32,12; Pwt 1,35-36; Joz 14,7.

${ }^{39}$ Por. Joz $14,6-15 ; 15,13-20 ; 21,12$.
} 
prawo dalszego mieszkania w Ziemi Obiecanej, każdy w swoim dziale, nawet jeśli przyszłoby im ponieść śmierć dla Boga. W przykładzie Kaleba ukazuje autor łączność między ziemią a wiernością Bożym poleceniom (klēronomia, dziedzictwo, por. także Syr 46,9-10) ${ }^{40}$.

\section{Dawid $(2,57)$}

Autor Pierwszej Księgi Machabejskiej uznał obietnicę proroka Natana skierowaną do Dawida za najważniejsze wydarzenie życia największego króla Izra$e^{4}{ }^{41}$. Trudność interpretacyjna pojawia się jednak w rozumieniu terminu eleos, najczęściej oddawanego przez 'miłosierdzie', 'współczucie', co jednak w odniesieniu do Dawida da się ukazać z wielkim trudem. Pierwsza i Druga Księga Samuela notują wprawdzie dwa przypadki miłosierdzia okazanego przez króla: rodowi Jonatana, syna Saula ${ }^{42}$, oraz Chanunowi, królowi Ammonitów ${ }^{43}$, lecz w obu chodzi raczej o wyraz wdzięczności za okazaną wcześniej pomoc i życzliwość. W drugim ponadto więzi łączące obu królów pogłębiły się już po obietnicy Bożej z $2 \mathrm{Sm}$ 7. Można, co prawda, wspomnieć jeszcze oszczędzenie życia Saula przez Dawida (1 Bas 26,9-12) czy pomoc dla Meribaala, syna Jonatana (2 Bas $9,7)$, lecz także w tych przypadkach nie jest to miłosierdzie motywowane wyłącznie dobrocią. Z kolei brak działania odwetowego względem Szimeiego (2 Bas 16,12-13) lub Absaloma (2 Bas 18,5) nie stanowi z pewnością podstawy tak wielkiego wyróżnienia króla przez Boga, tym bardziej że również te wydarzenia miały miejsce już po obietnicy Natana. Najlepszym odpowiednikiem nagrody od Boga dla Dawida może być podsumowanie jego życia w pieśni dziękczynnej 2 Bas 22,21-25, jakkolwiek nie ma tam wzmianki ani o miłosierdziu, ani o wieczystym tronie. $\mathrm{Z}$ drugiej strony nie można omawianego terminu eleos tłumaczyć przez 'pobożność', co może lepiej pasowałoby do całości życia króla ${ }^{44}$, jednak greka ma tu właściwy jej termin eusebeia. Być może trafniejszym odpowiednikiem byłaby 'wierność' lub 'życzliwość', 'łaskawość', notowana w hebrajszczyźnie terminem hesed ${ }^{45}$, co Septuaginta w odniesieniu do człowieka oddaje dość często właśnie przez eleos ${ }^{46}$, choć z drugiej strony 'wierny’ pasuje tu w najmniej-

\footnotetext{
${ }^{40} \mathrm{O}$ związku tej tradycji biblijnej z jej pierwowzorem w Joz 14,7-11, por. A.A. di Lella, The Wisdom of Ben Sira, s. 520.

${ }^{41}$ Por. 2 Bas 7,12-16.26 oraz Ps 88,38-38; 131,11.

${ }^{42}$ Por. 1 Bas 20,14-15; 2 Bas 9,1.

${ }^{43}$ Por. 2 Bas 10,2; 1 Par 19,2.

${ }^{44}$ Por. F. Gryglewicz, Księgi Machabejskie.

${ }^{45}$ Por. R. Doran, The first book of Maccabees, s. 51; R. Bultmann, eleos, eleeō, eleēmōn, ele$\bar{e} m o s y n \bar{e}$, aneleos, aneleēmōn, Theological Dictionary of the New Testament, t. II, W. B. Eerdmans Publ. Comp., Grand Rapids 1977, s. 479 (477-487).

${ }^{46}$ Por. m.in. Rdz 24,49; 40,14; Joz 2,12.14; Sdz 1,24; 8,35; Rt 3,10; 1 Bas 15,6; 20,8; 2 Bas 2,$5 ; 3,8$.
} 
szym stopniu, ponieważ greka ma $\mathrm{w}$ takim thumaczeniu kolejny termin pistos jako odpowiednik hebrajskiego rdzenia ' $m n$. W przypadku jednak Dawida chodziłoby wyłącznie o jego wierność Bogu, co sugeruje wypowiedź w 2 Bas 7,9. Za nią bowiem został ostatecznie nagrodzony ${ }^{47}$. Należy tu podkreślić, że wierność Dawida przyczynia się do zyskania pomocy od Boga przez Salomona. Tym samym staje się on beneficjentem wierności swego ojca ${ }^{48}$. Wpłynąc ma to bezdyskusyjnie na obecną postawę powstańców machabejskich, którzy manifestując swą wierność Bogu, zyskują Jego pomoc na tej samej zasadzie, co wcześniej Salomon.

\section{Eliasz $(2,58)$}

Zastosowanie w kolejnym wersecie Pierwszej Księgi Machabejskiej podwójnej składni $d z \bar{e} l \bar{o} s a i$ dzēlon jako charakterystyki postawy Eliasza, wielkiego proroka Starego Testamentu, przypomina postawę samego Matatiasza, nakreśloną w 2,24 na tle 3 Bas 19,10.14, gdzie znajduje się także ów podwójny zestaw terminologiczny. W obu przypadkach widać gorliwość ludzi, którzy walczą w obronie wiary w prawdziwego Boga nieugięcie, w całkowitym osamotnieniu, chociaż przewaga bałwochwalstwa w kraju wydaje się wręcz miażdżąca. Tymczasem w oporze wobec bałwochwalstwa nie jest ważna liczba wiernych, lecz hart ducha wypływający z osobistego przekonania o wartości wyznawanej wiary. Trzeba również podkreślić, że spotkanie Boga z prorokiem w rozdziale 3 Bas 19 poprzedzone było zgromadzeniem Izraelitów na górze Karmel, którego celem było ukazanie prawdziwości wiary w Boga narodu wybranego przeciw popularnym w narodzie kultom bałwochwalczym (3 Bas 18). Pojawia się także podobny kontekst konfrontacji obu kultów na oczach obserwatorów poprzez składane ofiary. Konfrontacja zaś kończy się zabiciem zwolenników bałwochwalstwa (3 Bas $18,40)$. Wreszcie za swą gorliwość prorok był prześladowany i musiał salwować się ucieczką (3 Bas 19,1-3), co spotkało także Matatiasza po zabiciu rodaka-wiarołomcy i urzędnika królewskiego. W ten sposób autor natchniony w mowie umierającego przywódcy, wspominając proroka, wskazuje także Matatiasza jako godnego naśladowania przez następców przejmujących dalsze losy powstania ${ }^{49}$. Jego związek z prorokiem uwidacznia się, tym bardziej że w w. 58 wspomina on gorliwość proroka o prawo (dzēlōsai dzēlon nomou), co charakteryzowało wła-

${ }^{47}$ W 3 Bas 8,25 przypomina tę wierność w modlitwie Salomona w nowo wybudowanej świątyni jerozolimskiej. Nie używa jednak wspomnianego terminu, lecz opis: ,jak ty wobec Mnie postępowałeś". Tak czy inaczej wierność ta zasadza się właśnie na kolejnych czynach króla, nie na deklaracjach, co ostatecznie zostało dostrzeżone przez samego Boga.

${ }^{48}$ Por. M.A. Sweeney, I \& II Kings. A Commentary, Old Testament Library, Westminster John Knox Press, Louisville 2007, s. 133-134.

${ }^{49}$ Por. D. Dimant, Use and Interpretation of Mikra in the Apocrypha and Pseudoepigrapha, w: J. Moulder, Mikra, Van Gorcum, Assen 1988, s. 394-395 (379-419). 
śnie Matatiasza i ściśle warunkowało przyłączenie się chętnych do powstania (dzēlōn tō nomō), podobna myśl obecna jest także w 2,27. Każdy więc zwolennik powstania powinien charakteryzować się taką samą gorliwością jak Matatiasz i jego ród. Niezachwiane przekonanie o wartości podjętej walki stanowi fundament całego udanego przedsięwzięcia. Ukazane w 2,24 okoliczności działalności Eliasza całkowicie odpowiadają czasom powstania, zwłaszcza jeśli chodzi o atak bałwochwalstwa i jego popularność w ziemi izraelskiej, dlatego obecnie warto jedynie przyjrzeć się samej końcówce jego życia, pojmowanej w obecnym wersecie jako nagroda za całokształt posługi. W przeciwieństwie bowiem do dziejów Dawida, przypomniane wydarzenie z życia proroka było ostatnim aktem jego ziemskiej aktywności (4 Bas 2,11). Wzięcie proroka do nieba w ognistym wozie i koniach podczas marszruty z Elizeuszem, jego następcą na urzędzie prorockim, nie może być bowiem oceniane jako jeszcze jeden epizod z życia Eliasza, lecz ewidentnie jako ukoronowanie całości jego wiernej posługi Bogu ${ }^{50}$. Być może jednak autor biblijny ma tu na myśli dwa specjalne wydarzenia, które ukazuja proroka broniącego prawa. Oto przejmując winnicę Nabota, król Achab przekroczył zarówno IX, jak i V przykazanie dekalogu (1 Krl 21,1-16) oraz pogwałcił prawo własności dziedzicznej (Lb 36,9), wraz zaś ze swoją żoną, Izebel, prze-

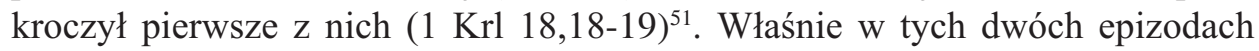
widać najwyraźniej zdecydowaną postawę proroka w obronie prawa Bożego, chociaż należy tu dodać także zdarzenie na górze Karmel i wycięcie proroków bożków pogańskich, co było jaskrawym przykładem oddania Eliasza sprawie Bożej (1 Krl 18,19-40). Każde z tych wydarzeń można jednakowo odnieść do obecnej walki powstańców machabejskich, ich bowiem walka o prawo Boże dokonuje się zarówno na płaszczyźnie wolności kultycznej, jak i sprawiedliwości społecznej. W obu tych sferach powinni więc wykazywać się tą samą gorliwością jaką charakteryzował się największy prorok historii Izraela.

\section{Chananiasz, Azariasz, Miszael $(2,59)$}

Historia trzech młodzieńców w piecu ognistym zawarta jest w Księdze Daniela (Dn 3,23) i stanowi dość znaczny przeskok historyczny w argumentacji umierającego Matatiasza. Pominięta została spora grupa proroków i innych, wybitnych postaci dziejów Izraela, jak choćby Nehemiasz, w których życiu nietrudno znaleźć próby, jakim Bóg poddał ich wiarę i wierność. Być może jednak chciał się autor natchniony skupić na przedstawicielach najważniejszych nurtów literackich Starego Testamentu lub kolejnych ważnych epok w historii narodu wybra-

\footnotetext{
${ }^{50}$ Jako widzialny przejaw boskiej obecności, trwającej przy proroku przez całe jego życie, por. V. Fritz, $1 \& 2$ Kings. A Continental Commentary, Fortress Press, Minneapolis 2003, s. 235-236.

${ }^{51}$ Por. J.R. Bartlett, The First and Second Books of the Maccabees, Cambridge Biblical Commentary, Cambridge Univ. Press, Cambridge 1973, s. 43.
} 
nego. Obok patriarchów znaleźli się przedstawiciele okresu wyjścia i zajmowania Ziemi Obiecanej, epoki przedwygnaniowej, prorocy, a wreszcie członkowie narodu już po powrocie z niewoli, bliżsi czasom machabejskim. To właśnie miejsce zajmują obecnie trzej młodzieńcy, zaraz zaś po nich Daniel, w tradycji żydowskiej przedstawiciel nurtu nie prorockiego, lecz mądrościowego. Poza tym w Księdze Daniela akcja utworu przeniesiona została na czasy babilońskiego króla Nabuchodonozora, stanowiącego dla autora Pierwszej Księgi Machabejskiej teologiczny pierwowzór postawy i działań Antiocha IV Epifanesa, głównego wroga Żydów tej epoki. Umieszczenie imion własnych Chananiasza, Azariasza, Miszaela, podanych w tej samej kolejności zarówno w Pierwszej Księdze Machabejskiej, jak i greckim tekście Księgi Daniela wskazuje, że właśnie ona jest pierwowzorem Pierwszej Księgi Machabejskiej, przy czym tekst Księgi Daniela, nieco wcześniejszy, zwłaszcza w modlitwie Azariasza (3,26-45), naświetla znacznie lepiej sytuację przeżywaną aktualnie przez Izraelitów ciemiężonych przez odstępców od prawa oraz króla seleuckiego jako karę za niewierność postanowieniom przymierza. Modlitwa ta zawiera wszystkie elementy sytuacji wynikającej z prześladowań i tę samą jej ocenę teologiczną (w. 28-32; wersja Septuaginty i Teodocjona) ${ }^{52}$ : nieszczęścia spadające na naród i jego stolicę z woli Bożej jako konsekwencja jego grzechów (w. 28), uświadomienie sobie własnych nieprawości wobec Boga jako źródła obecnych tragedii narodowych (w. 29), zatwardziałe nieposłuszeństwo prawu Bożemu mimo całkowitej świadomości własnych występków (w. 30), sprawiedliwość Bożych wyroków ujawniających się w obecnych niepowodzeniach (w. 31), niewola i panowanie obcych władców i odstępców od prawa ${ }^{53}$ nad Izraelem jako konsekwencja zepsucia moralnego i bezbożnictwa pośród Izraelitów (w. 32). Takie teologiczne naświetlenie doskonale wręcz pasuje do oceny, jaką autor Pierwszej Księgi Machabejskiej wydaje o sytuacji swych pobratymców na krótko przed wybuchem powstania. Należy także wnosić, że przywołanie całego zdarzenia przez Matatiasza ma uzasadnienie bardziej w wystapieniu młodzieńców przeciw bałwochwalczym zapędom króla Nabuchodonozora, bowiem odważnie odmówili uczczenia jego posagu. Ich postawa czerpie zarówno $\mathrm{z}$ wiary $\mathrm{w}$ jedynego Boga, jakim jest wyłącznie Bóg Izraela, oraz z ufności, że za wierność zostaną nagrodzeni wyrwaniem z rąk króla, a także jest silnym świadectwem prawdziwości wiary wobec pogańskich

\footnotetext{
${ }^{52}$ Por. M. Parchem, Księga Daniela, Nowy Komentarz Biblijny - Stary Testament, t. XXVI, Ed. św. Pawła, Częstochowa 2008, s. 287.

${ }_{53}$ Autor Księgi Daniela nazywa ich echthistoi apostatai, «najgorszymi apostatami», jednak w wersji Septuaginty oddzieleni są oni od echthrōn hēmōn anomōn, «nieprawych naszych nieprzyjaciół» spójnikiem kai, «i», podczas gdy wersja Teodocjona nie stawia tego spójnika, dając wrażenie, iż to owi obcy nieprzyjaciele są apostatami. Można stąd chyba wnosić, że autor Pierwszej Księgi Machabejskiej miał przed sobą tekst wersji Septuaginty, ponieważ lepiej odpowiadał on sytuacji nakreślonej przez niego w epoce powstania antyseleuckiego.
} 
oprawców (3,16-18). Odważna obrona własnej religii została w końcu nagrodzona specjalną interwencją anioła Pańskiego (3,25.28 TH; w. 49-50 LXX), co pozwoliło ostatecznie ocalić życie wszystkim trzem młodzieńcom $(3,26-27 \mathrm{TH}$; w. 93 LXX) i doprowadziło nawet pogańskiego króla do wyznania wiary w Boga Izraela (3,28-29 TH; w. 95-96 LXX). Możliwe jest, że w Pierwszej Księdze Machabejskiej autor biblijny, będąc zwolennikiem saduceuszów, chciał uniknąć wspominania duchów niebiańskich i właśnie dlatego w powstańcach ukazał wysłanników Boga ratujących swój lud, jak anioł uratował młodzieńców w piecu ognistym. Podany przykład młodzieńców świadczy o tym, że tego typu historie były opowiadane w czasach walki o wyzwolenie narodu dla zachęty do stawiania oporu poganom ${ }^{54}$.

\section{Daniel $(2,60)$}

Ostatnie już odwołanie Matatiasza do konkretnej postaci historii Izraela jest zarazem drugim z Księgi Daniela i pokazuje inną próbę wiary, jaką tym razem miał przejść główny bohater tekstu natchnionego w jaskini lwów (6,1-28). Definiując postawę Daniela, autor Pierwszej Księgi Machabejskiej użył terminu $h a-$ plotēs, 'prawość, szczerość, prostolinijność', nieznanego w Księdze Daniela ${ }^{55}$. Cecha ta owocowała wiernością Bogu, zwłaszcza w obliczu śmierci, jak to już pokazał cytat 1 Mch 2,37 wspominający prawość męczenników umierających za wierność szabatowi. Możliwe zatem, że rzeczownik ten także w w. 60 użyty został celowo, aby ukazać podobieństwo postaw obu bohaterów świadczących o swej wierności Bogu w tych samych okolicznościach bezpośredniego zagrożenia śmiercią. Natomiast w Księdze Daniela haplotēs przedstawiona została opisowo jako uwielbienie składane przez Daniela swemu Bogu w ziemi niewoli trzy razy dziennie w formie modlitwy poprzez padanie na twarz (6,11 LXX). Jest to zewnętrzne wyznanie wiary i jej świadectwo wobec innych ludzi ${ }^{56}$. Powyższy termin obejmuje również to, co sam Daniel oświadczył, mówiąc o swej niewinności względem Boga i króla $(6,23 b)$ oraz ufności złożonej w Bogu $(6,24)^{57}$. Ta sama niewinność w oczach Boga Izraela powinna zatem charakteryzować powstańców, a wyrażać się bezwzględnym posłuszeństwem Jego prawu, zwłaszcza

${ }^{54}$ Por. J.R. Bartlett, The First and Second Books of the Maccabees, s. 43.

${ }^{55}$ Opisowy odpowiednik tego terminu znajduje się natomiast w 6,23, jako dikaiosynē en emoi heurethe enantion autou, 'odkryta została przed Nim we mnie sprawiedliwość'. Chodzi zatem o niewinność pojmowaną jako uczciwość i szczerość wobec Boga i człowieka, por. J. Phillips, Exploring the Book of Daniel. An Expository Commentary, Kregel Publ., Grand Rapids 2004, s. 105.

${ }^{56}$ Por. m.in. 1 Mch 4,40.55; Lb 14,15; 16,4.22; 17,10; 20,6; Joz 7,6.10; Sdz 13,20; 3 Bas 18,39; 2 Par 7,3; Jdt 4,11; 9,1; Syr 50,17.

${ }^{57}$ Niewinność tę, określoną w hebrajskim źródłosłowie mianem zākû, należy rozumieć w sensie prawniczym, jako postępowanie nienaganne wobec przepisów, por. L.F. Hartman, A.A. di Lella, The Book of Daniel. A New Translation with Introduction and Commentary, The Anchor Bible 23, New York-London-Toronto-Sydney-Auckland 2005, s. 196. 
w trudnych okolicznościach życia i w niebezpieczeństwach. Siła wiary Daniela uwidoczniła się zatem w wierności, gdyż był świadomy skutków niepodporządkowania się królewskiemu dekretowi, co oznaczało dla niego śmierć w jaskini lwów $(6,13)$, czego też nie omieszkano wykorzystać przeciw niemu $(6,12.14)^{58}$. Nagrodą było znów - jak w przypadku trzech młodzieńców - wyratowanie od śmierci przez Boga dzięki bezpośredniej interwencji anioła (6,23a). Warto przy tym dodać, że grecki tekst Księgi Daniela ściśle tłumaczy swój hebrajski pierwowzór w wersji Teodocjona, natomiast wersja Septuaginty zawiera zdanie bliższe sensowi tłumaczenia greckiego Pierwszej Księgi Machabejskiej, gdzie nie ma mowy o posłaniu anioła przez Boga: „I wybawił mnie Bóg od lwów, ponieważ znalazł we mnie sprawiedliwość [dikaiosynē] przed sobą i przed tobą, królu. Nie znalazł zaś we mnie ani uchybienia [agnoia], ani nieprawości [hamartia]". Te zatem cechy składają się na to, co autor w naszej księdze określił mianem haplotês Daniela. Tą samą wiernością Bogu powinni charakteryzować się także powstańcy machabejscy.

\section{Podsumowanie teologiczne $(2,61)$}

Ostatnia część wypowiedzi Matatiasza wskazuje, że powyższe przykłady były jedynie niewielką egzemplifikacją całego ciągu wielkich postaci w historii Izraela, których najważniejszą charakterystykę życia stanowiła bezwzględna wierność Bogu, fundowana na zaufaniu w Jego moc i sprawiedliwość. Każde z minionych pokoleń może dostarczyć kolejnych przykładów takich osobowości, z których zarówno naród, jak i szczególnie powstańcy powinni być dumni i do naśladowania których powinni być gotowi. Autor milcząco włącza tu z pewnością również proroków (Iz 26,8; Ba 4,22) i całe społeczności (Dn 13,60).

Ufający Bogu określeni zostali jako elpidzontes ep'auton ('ufający Mu'), zwrot klasyczny dla tekstów poetyckich ${ }^{59}$. Natomiast 1 Par 5,20 oraz 2 Par 13,18 są tu o tyle godne wzmianki, że używają omawianego zwrotu w kontekście militarnym, akcentując właśnie zaufanie Bogu jako istotny element zwycięskiej walki. W myśl pierwszego $\mathrm{z}$ nich owo zaufanie zaowocowało $\mathrm{z}$ jednej strony pomocą otrzymaną od współbraci, z drugiej zaś bezpośrednią pomocą Boga, który zagwarantował im zwycięstwo $\mathrm{w}$ walce ${ }^{60}$. W drugim tekście należy podkreślić zwłaszcza nierównomierność sił walczących stron, co ukazuje przede wszystkim

\footnotetext{
${ }^{58}$ Por. S.R. Miller, Daniel. An Exegetical and Theological Exposition of Holy Scripture, New International Version - New American Commentary 18, Broadman \& Holman Nashville 1994, s. $186-187$.

${ }^{59} 40$ razy w psalmach; por. także Syr 2,6; Dn 3,28.

${ }^{60}$ Jest to zgodne z ogólnymi zamierzeniami teologii autora kronikarskiego, por. H. Langkammer, Pierwsza i Druga Księga Kronik. Tłumaczenie, wstęp i komentarz, w: Pismo Święte Starego i Nowego Testamentu w przekładzie z języków oryginalnych, RW KUL, Lublin 2001, s. 66.

${ }^{61}$ Teologia historii autora kronikarskiego wyraża się tu faktem, że jedynie w Judzie zachowa-
} 
niezbędność Bożej pomocy i wartość zaufania w Nim położonego ${ }^{61}$. Znacząco zbliża to oba teksty do aktualnego Machabeuszom kontekstu sytuacyjnego. Nowotestamentowy cytat $1 \mathrm{Tm} 4,10$ walkę tę przenosi już na grunt duchowy, chociaż w kontekście stricte sportowym ${ }^{62}$.

Używając natomiast czasownika astheneō ('słabnę', 'staję się słaby') w połączeniu z elpidzō, autor mógł sięgnać do brzmienia $P s$ 25,1 zawierającego oba wzmiankowane czasowniki w tym samym sensie, chociaż drugi z nich w znaczeniu negatywnym: psalmista nie zachwieje się właśnie dlatego, że ufa bezgranicznie Bogu, zaś jego niewinność jest znakiem tego zaufania. $Z$ tej właśnie racji nie obawia się on Bożego osądu. Przeciwnie, prosi o niego jako potwierdzenie obranej przez siebie drogi ${ }^{63}$. Tekst ów może doskonale podsumować trzy najważniejsze cechy postawy wszystkich bohaterów historii narodu przywołanych przez Matatiasza: wierność Bogu w codziennym postępowaniu, nadzieję w Nim złożoną i wytrwanie do końca $\mathrm{w}$ czasie próby. Właśnie na tych trzech filarach musi się obecnie oprzeć walka powstańców.

\section{Teologia tekstu 1 Mch 2,51-61}

Kusząc się o dokonanie generalnego podsumowania natury teologicznej, można poczynić kilka wartościowych obserwacji:

a) mowa Matatiasza nawiązuje do wielkiej historii Izraela, ustanawiając związek między obecną walką powstańców a podobnymi epizodami z przeszłości narodu, aby uniknąć poczucia jej odosobnienia;

b) walka powstańców jest kolejnym i ważnym etapem zmagań Izraela o jego wiarę i wierność Bogu, co decydująco wpływa na poczucie jego tożsamości narodowej i religijnej;

c) powstańcy mogą stawić siebie w rzędzie szlachetnych przodków Izraela, podejmujących walkę o jego przetrwanie, zapewniając swym rodakom

ne zostały: prawowita dynastia Dawidowa oraz prawdziwy kult Boga, podczas gdy w Izraelu zapanowały: odszczepieństwo i schizma. Konsekwencją staje się wówczas wierność Boga pokoleniu Judy, nie królestwu północnemu (1 Krn 13,5-12), por. F. Michaeli, Les Livres des Chroniques, d'Esdras et de Néhémie, Commentaire de l'Ancien Testament XVI, Delachaux et Niestlé, Neuchâtel 1967, s. 177-178.

${ }^{62}$ Co jednak w niczym nie zmienia jej reguł, a nawet je wzmacnia: zwłaszcza bowiem prowadząc bój z niewidzialnym przeciwnikiem o wiele silniejszym i sprawniejszym od człowieka, należy całe zaufanie bezwzględnie położyć w Bogu, który jako jedyny gwarantuje zwycięstwo. Walka ta jest z definicji trudniejsza i bardziej konieczna dla życia człowieka od znoszenia przeciwności fizycznych, por. W.D. Mounce, The Pastoral Epistles, Word Biblical Commentary 46, Thomas Nelson Publishers, Nashville 2000, s. 254-257.

${ }^{63}$ Por. S. Łach, Księga Psalmów. Wstęp - przekład z oryginału - komentarz, w: Pismo Święte Starego Testamentu, t. VII-2, Pallottinum, Poznań 1990, s. 189-190. 
możliwość dalszej egzystencji, zwłaszcza religijnej, jako narodu monoteistycznego;

d) przygotowują sobie $w$ ten sposób podobną sławę i wspomnienie u potomnych, jak to ma miejsce w przypadku wychwalanych, wielkich przodków ludu;

e) warunkami niezbędnymi do osiagnięcia zwycięstwa jest całkowita wierność prawu Bożemu oraz ufność w Jego niezawodną pomoc, która nadejdzie w oznaczonym przez Niego czasie;

f) sama Pierwsza Księga Machabejska wpisuje się w ciąg ksiąg historycznych Starego Testamentu, podejmując ten sam temat wspomnienia tych, którzy przyczynili się do przetrwania Żydów jako ludu Bożego pierwszego wezwania.

\section{Summary}

The core of Mattathias' deathbed speech addressed to his sons and all the participants of the Maccabaean rising (1 Macc 2:51-61) is the command to be faithful to the law and the covenant as a foundation of patriotism as it was then understood - love of one's homeland and defense of traditions that constituted the identity of the people who inhabited it. The biblical author recalls the major figures in the history of Israel to show the struggle of the insurgents as a continuation of the history created by the heroes of the past. The object of the article is to present the theology of those particular figures from the history of Israel in the context of the then ongoing events whereby they became models to follow and a source of perseverance in the undertaken struggle against the pagan invaders from the Seleucid empire.

\section{Keywords}

Bible, Old Testament, Septuagint, The First Book of Maccabees, biblical theology, biblical exegesis, Maccabee rising

\section{Slowa kluczowe}

Biblia, Stary Testament, Septuaginta, Pierwsza Księga Machabejska, teologia biblijna, egzegeza biblijna, powstanie machabejskie

\section{Bibliografia}

Ashley T.R., The Book of Numbers, The New International Commentary on the Old Testament, Eerdmans Publ. Comp., Grand Rapids 1993.

Bartlett J.R., The First and Second Books of the Maccabees, Cambridge Biblical Commentary, Cambridge Univ. Press, Cambridge 1973.

Bultmann R., eleos, eleeō, eleēmōn, eleēmosynē, aneleos, aneleēmōn, Theological Dictionary of the New Testament, t. II, W. B. Eerdmans Publ. Comp., Grand Rapids 1977, s. $477-487$. 
Christensen D.L., Deuteronomy 21:10-34:12, Word Biblical Commentary 6B, Word Books Publ., Dallas 2002.

di Lella A.A., The Wisdom of Ben Sira. A New Translation with notes by P.W. Skehan. Introduction and Commentary, The Anchor Bible 39, New York-London-Toronto-Sydney-Auckland 1987.

Dimant D., Use and Interpretation of Mikra in the Apocrypha and Pseudoepigrapha, w: J. Moulder, Mikra, Van Gorcum, Assen 1988, s. 379-419.

Doran R., The first book of Maccabees, The new interpreter's Bible, red. L.E. Keck, D.L. Petersen, t. 4, Abingdon, Nashville 1996.

Doré D., Le Livre de Judith ou la guerre et la foi, « Cahiers Évangile » 132, Cerf, Paris 2005.

Fritz V., 1 \& 2 Kings. A Continental Commentary, Fortress Press, Minneapolis 2003.

Gilbert M., Les cinq livres de Sages: Les Proverbes de Salomon. Le livre de Job. Qohélet ou l'Ecclésiaste. Le livre de Ben Sira. La Sagesse de Salomon, Lire la Bible, Cerf, Paris 2003.

Goldingay J., Psalms 1: Psalms 1-41, Baker Commentary on the Old Testament: Wisdom and Psalms, T. Longman III (wyd.), Baker Academic, Grand Rapids 2006.

Goldingay J., Psalms 3: Psalms 60-150, Baker Commentary on the Old Testament: Wisdom and Psalms, T. Longman III (wyd.), Baker Academic, Grand Rapids 2008, s. $237-$ $-238$.

Gryglewicz F., Księgi Machabejskie. Wstęp - przekład z oryginału - komentarz, w: Pismo Święte Starego Testamentu, red. S. Łach, t. 6, cz. 4, Pallottinum, Poznań 1961.

Guthrie D., Hebrews, The Tyndale New Testament Commentary, InterVarsity Press, Grand Rapids 1983.

Hartman L.F., di Lella A.A., The Book of Daniel. A New Translation with Introduction and Commentary, The Anchor Bible 23, New York-London-Toronto-Sydney-Auckland 2005.

Langkammer H., Księga Tobiasza. Księga Judyty. Księga Estery. Ttumaczenie, wstęp i komentarz, Pismo Święte Starego i Nowego Testamentu w przekładzie z języków oryginalnych, Redakcja Wydawnictw KUL, Lublin 2001.

Langkammer H., Pierwsza i Druga Księga Kronik. Tłumaczenie, wstęp i komentarz, Pismo Święte Starego i Nowego Testamentu w przekładzie z języków oryginalnych, Redakcja Wydawnictw KUL, Lublin 2001.

Levine B.A., Numbers 21-36. A New Translation with Introduction and Commentary, The Anchor Bible 4A, Doubleday, New York-London-Toronto-Sydney-Auckland 2000.

Łach S., Księga Psalmów. Wstęp - przekład z oryginatu - komentarz, w: Pismo Święte Starego Testamentu, t. VII-2, Pallottinum, Poznań 1990, s. 189-190.

Mathews K.A., Genesis 11:27-50:26. An Exegetical and Theological Exposition of Holy Scripture, New International Version - New American Commentary 1B, Broadman \& Holman Nashville 2005.

Merrill E.H., Deuteronomy. An Exegetical and Theological Exposition of Holy Scripture, New International Version - New American Commentary 4, Broadman \& Holman Nashville 1994. 
Michaeli F., Les Livres des Chroniques, d'Esdras et de Néhémie, Commentaire de l'Ancien Testament XVI, Delachaux et Niestlé, Neuchâtel 1967.

Miller S.R., Daniel. An Exegetical and Theological Exposition of Holy Scripture, New International Version - New American Commentary 18, Broadman \& Holman Nashville 1994.

Mounce R.H., Romans. An Exegetical and Theological Exposition of Holy Scripture, New International Version - New American Commentary 27, Broadman \& Holman Nashville 1995.

Mounce W.D., The Pastoral Epistles, Word Biblical Commentary 46, Thomas Nelson Publishers, Nashville 2000.

Mrozek K., Rdzeń zkr w aspekcie pamięci o Bogu w Księdze Psalmów. Analiza egzegetyczno-teologiczna, Wydział Teologiczny UAM, Poznań 2013, ss. 330 (nieopubl.).

Parchem M., Księga Daniela, Nowy Komentarz Biblijny - Stary Testament, t. 26, Ed. św. Pawła, Częstochowa 2008.

Phillips J., Exploring the Book of Daniel. An Expository Commentary, Kregel Publ., Grand Rapids 2004.

Richardson K.A., James. An Exegetical and Theological Exposition of Holy Scripture, New International Version - New American Commentary 36, Broadman \& Holman Nashville 1997.

Schedl C., Księga Tobiasza, Historia Starego Testamentu, t. 5: Ku petni czasu, Tuchów 1995.

Sweeney M.A., I \& II Kings. A Commentary, Old Testament Library, Westminster John Knox Press, Louisville 2007.

Synowiec J.S., Mędrcy Izraela, ich pisma i nauka, wyd. Bratni Zew, Kraków 1990.

Wojciechowski M., Apokryfy z Biblii greckiej, Rozprawy i Studia Biblijne 8, Vocatio, Warszawa 2001.

Wojciechowski M., Księga Tobiasza, czyli Tobita, Nowy Komentarz Biblijny - Stary Testament, t. 12, Ed. św. Pawła, Częstochowa 2005. 